\title{
JOHN EVELYN'S SALADS
}

\author{
BY C. F. MAIN
}

Dr. Main is Professor of English and Director of Research in the Office of Research and Sponsored Programs at Rutgers University.

T N I 668, less than three years after the Royal Society of London was founded, Robert Boyle published in the Society's Philosophical Transactions a long list of "Inquiries Concerning the Use of the Kitchin-Garden and Winter Greens." He proposed these inquiries as topics for research, and among them he included this question: "What herbs are fit to make Sallets, and how are they to be ordered for that purpose?" We may be mildly surprised not only to find a question like this one called a "philosophical transaction," but also to remember that the questioner, Robert Boyle, is famous for formulating a fundamental law describing the behavior of gases. But such diversity of interests is quite usual in the unspecialized seventeenth century, when the term "philosophy" covered, among other studies, both theoretical and applied science. In its early years the Royal Society's Transactions did for its readers what many different journals do today: it was their Mind, Nature, and Physical Review as well as their Poultry Science, Good Housekeeping, and National Geographic Magazine. And so far from embarrassing his fellow members of the Society, Boyle inspired one of them, John Evelyn, to write and publish a book which he entitled Acetaria: A

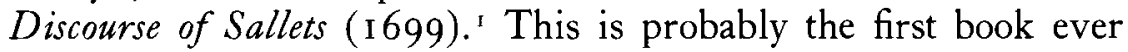
written on salads, and quite likely the last "philosophical" one. What's more, John Evelyn actually knew how to put together a green salad and dress it properly with oil and vinegar - a culinary art that has not always been practiced in England since his time.

Like his contemporary Samuel Pepys, Evelyn (I620-I706) is best known today for the important diary or Kalendarium he kept throughout most of his life. Pepys and Evelyn were friends, but theirs must have been an attraction of opposites, the one being a complete Londoner, interested in money, women, good living, the

\footnotetext{
' No. E 3480 in Donald Wing's Short-Title Catalogue. The copy in the Rutgers University Libraries' Special Collections, a gift of Mr. Philip D. Sang, was originally presented to Philip Stanhope, second Earl of Chesterfield, with this holograph inscription on the fly leaf: "For the Rigt Honor ble the Earle of Chesterfield from his old, most humble servant J Evelyn."
} 
theater, and court gossip and politics; the other, a complete country gentleman and serious student of gardens, architecture, sculpture, and Greek and Roman literature. While Pepys was a lifelong civil servant and successful bureaucrat, Evelyn was a private man of means who volunteered his services to the public: he took charge of the wounded in the Dutch War, he organized the government's medical services-such as they were-during the Plague, he wrote many useful books including the first and for long the only book on air pollution (characteristically titled Fumifugium), he was a commissioner for improving the streets and buildings of London, and he was one of the founders and first secretary of the Royal Society. It's scarcely necessary to add that his diary is very useful to historians but lacks the sparkle and intimacy of Pepys's. Indeed, the Acetaria may be the only work by Evelyn that is both informative and entertaining.

Evelyn realized that some people might regard the subject of salads as "low," and that his book might cause ridicule of himself and detraction of the Royal Society. Although no theater-goer, he must have recognized himself as a kind of virtuoso-the label applied to the scientist-collectors of the day. The virtuoso was a stock object of satire on the Restoration stage-weighing air, measuring the distance to the moon, gathering molds and scums and peering at them through magnifying glasses, while his pretty young wife is being solaced by the hero of the comedy. More serious critics of the Society asked why men should be concerned with mites and specks and other phenomena low down on the Great Chain of Being. Such futile and trivial pursuits were hardly appropriate for a race created in God's own image. Evelyn faced this sort of criticism directly in his dedication of Acetaria to John, Lord Somers of Evesham, Lord High Chancellor of England and President of the Royal Society:

My Lord, I expect some will wonder what my Meaning is, to usher in a Trifle, with so much Magnificence, and end at last in a fine Receipt for the Dressing of a Sallet with a Handful of Pot-Herbs! But yet, My Lord, this Subject, as low and despicable as it appears, challenges a Part of Natural History; and the Greatest Princes have thought it no Disgrace not only to make it their Diversion, but their Care, and to promote and encourage it in the midst of their weightiest Affairs: He who wrote of the Cedar of Libanus, wrote also of the Hysop which grows upon the Wall. 
The last sentence apparently refers to no less a writer than King David, who mentions the cleansing power of the herb hyssop in Psalm 51 and the majesty of the cedars of Lebanon in Psalm 92.

Having proclaimed the dignity and importance of his subject, Evelyn's whole effort is to keep it elevated, in the spirit of his younger contemporary Alexander Pope, who took pains in his translations of Homer to give heroic stature to some of the low matters he found in the Greek originals. This elevated treatment of a humble subject provides much of the pleasure of Acetaria. The Latin title of the book, for instance, is a word Pliny used in his Natural History meaning, of course, salads, foods dressed with vinaigrette sauces, as Evelyn is at pains to point out in his subtitle, "A Discourse of Sallets." The pages he devotes to defining salad or sallet (an old form still extant in the "poke sallet" of the Ozarks) bristle with Latin and Greek words and phrases, with references to the Bible, Ovid, Plutarch, Galen, Theophrastus, Pliny, Salmasius. We are back in the world of Burton's Anatomy of Melancholy, lost in a maze of quotations and digressions. Evelyn's memory, like Burton's, is overstocked, his ambitions encyclopedic. In a prefatory chapter entitled "The Plan of a Royal Garden" he outlines an enormous botanical-horticultural work that he is planning to write; Acetaria is only one of forty-two different but related subworks that will comprise the whole. Bacon, the patron saint of the Royal Society, clearly provides a model here as well as a precedent for not bringing the whole scheme to completion. And like Evelyn, Bacon appears to have been a salad eater; in his History of Life and Death (I623) he particularly recommends watercress dressed with oil and vinegar for strengthening the liver.

The classical learning displayed in Acetaria is not pedantic decoration; it is there to give salad-eating prestige, to demonstrate that salads were an integral part of classical civilization and therefore should be of English, especially since the ancients lacked many of the salad ingredients now available. Evelyn's aim is to enhance the reputation of salads as an item in the English diet. While it is possible to find salads recommended in herbals and even praised in cookery books, such as Robert May's The Accomplish't Cook (i685), their general reputation, if literary evidence may be relied on, was not very high. Salads were associated, in the words of Milton's Comus, with "lean and sallow Abstinence." Volpone, dis- 
guised as a quack doctor in Jonson's comedy, sneers at "your shrivell'd sallad-eating artizans," and in the introduction to his masque Hymenaei Jonson contrasts his own "full tables" providing "nourishing and sound meates" with "Italian herbs, pick'd up and made into a sallade." Furthermore-Jonson is clearly one of Evelyn's "profest Enemies of sallet" — a noisome passage in "On the Famous Voyage" warns against approaching the public privies of London when "Laxative lettuce" is in season. Salads are for mad men and Papists, according to Jonson's contemporary Donne, who sneers at a proud but penniless courtier in one of his epigrams:

The Liar

Thou in the fields walk'st out thy supping hours, And yet thou swear'st thou hast supp'd like a king: Like Nebuchadnezar perchance with grass and flowers, A sallet worse than Spanish dieting.

Henry Peacham, in The Complete Gentleman (I622), explains why the Spanish eat so many salads: "Being by constitution hot and dry, they are not able to digest more solid meats." Salads are un-English, according to Thomas Gainsford's The Glory of England (I6 I 8). In answer to the question why Italian animals are so "few, small, and leane," Gainsford explains that "the Italians devour the grasse in sallets, and rob the pastures to deceive the poor cattle." Centuries later, Dickens, in Barnaby Rudge, commends the voluntary asceticism of missionaries in foreign parts, who live chiefly on salads. Citations of this sort could, as they say, be almost endlessly multiplied. Even what looks like a kind word about salads is often not, as when Sir Thomas Browne boasts in Religio Medici (1642) that he could "digest a Sallad gathered in a Church-yard, as well as in a Garden." Browne is proclaiming his affinity for death, not for lettuce.

To show that England affords ample materials for salads, Evelyn devotes about one-fourth of Acetaria to discussing, in alphabetical order, the available ingredients, or "furniture." His nomenclature is curious in a pedantic way: salad dressing is, variously, "oxoleon," "oxybaphon," "vehicle," or "intinctus"; garnishes are "strewings"; young tender vegetables are "oluscula"; very young pea pods are "a pretty Acid." What we call vegetables Evelyn usually calls "herbs"; he uses the word vegetable only in such expressions as "the vegetable 
kingdom," which includes oak trees as well as cabbages. In all, Evelyn has seventy-three items on his list of "Furniture and Materials." They might be conveniently sorted into five somewhat arbitrary and overlapping categories and given the following modern labels: salad greens, culinary herbs, medicinal herbs, vegetables, and edible weeds. I will mention only a few representative items in each category, leaving the remainder for those interested in consulting Acetaria itself.

In the category of greens, Evelyn lists endive and spinach (which "may be had at almost any Season, and in all places"), but his longest entry, and the one most enriched by classical quotations, is devoted to a rhapsody on lettuce, "the principal Foundation of the universal Tribe of Sallets." He mentions eighteen different kinds of lettuce- "to name a few in present use." Iceberg, the ubiquitous and imperishable achievement of modern agriculture, does not of course appear on Evelyn's list-a fact that may help account for his enthusiasm for "this Noble Plant," which "allays Heat, bridles Choler, extinguishes Thirst, excites Appetite, kindly Nourishes, and above all represses Vapours, conciliates Sleep, mitigates Pain; besides the effect it has upon the Morals Temperance and Chastity." The last-mentioned effect is a somewhat veiled reference to the alleged power of lettuce to suppress sexual desires by "cooling the blood." Shakespeare was apparently alluding to this belief when he had Cleopatra refer to the time when she was young and virginal as "my salad days when I was green in judgment and cool in blood." At the other end of the seventeenth century, Dryden's Hind, in The Hind and the Panther, "cooled her blood" with a "Lenten sallad." The Elizabethan satirists liked to make sniggering references to lettuce: Joseph Hall, in Virgidemiae ( 1598 ), described a male prude as follows:

Virginius vow'd to keep his Mayden-head, And eats chast Lettuce, and drinks Poppy-seed, And smels on Camphyre fasting.

And John Marston, in The Scourge of Villanie (1 598), scolded a licentious age for avoiding "chaste" foods and eating exotic aphrodisiacs such as potatoes and eryngoes (candied sea-holly roots):

Camphire and Lettuce chast,

Are cleane casheird, now Sophi Ringoes eate,

Candid Potatoes are Athenians meate. 
"The anaphrodisiac powers of lettuce are everyday knowledge," according to a letter printed in the Times Literary Supplement for October 6, 1978. And so a mere glance at this property of lettuce is sufficient for Evelyn, who is unusual among Restoration figures in having nothing to say about sex, in people or plants. He frequently refers to his friend "the learned Dr. Grew," but he never tells us that Nehemiah Grew was a pioneer investigator of sex in plants.

According to a traditional classification of foods that was part of Evelyn's intellectual inheritance, salad greens are, on the whole, "cold and moist." Just as human bodies are composed of four humors (choler or bile, which is hot and dry; blood, which is hot and moist; phlegm, which is cold and moist; and black bile, the melancholic humor, which is cold and dry), so human foods are composed of the same primary qualities. A proper diet is thus one that not only nourishes a body, but also corrects imbalances in its humors. At times Evelyn seems suspicious of this ancient doctrine, as when he refers to the humors as "vulgarly reputed." $\mathrm{He}$ also, by the way, refers to the traditional four elements (earth, air, fire, water) as "vulgarly reputed." The elements and the humors were of course a part of a single great system, which was just beginning to break down in Evelyn's day. As a member of the Royal Society, Evelyn sensed that the old "philosophy" was gradually being replaced by several different sciences based on observation; yet as a writer on practical matters of diet he frequently found much of the old terminology convenient. And so he uses such terms as hot, cold, moist, and dry as though they are merely descriptive adjectives. After all, lettuce is, or should be, cold and moist, pepper is hot and dry. What is new in Evelyn is his refusal to indicate the degree of the primary qualities in his plant foods. While his cucumbers are merely "cold and moist," the cucumbers of one of his predecessors, the herbalist John Gerard, are "cold and moist in the second degree."

So much for the category of salad greens, whose qualities of coldness and moisture are balanced by such hot and dry culinary herbs on Evelyn's list as rocket, rosemary, sage, tarragon, basil, and burnet or pimpernel. Pepper is one of Evelyn's enthusiasms: "It is a never to be omitted ingredient of our Sallets," he says. But he warns against pepper that is finely ground, or "too minutely beaten" because it "adheres and sticks in the folds of the Stomach, 
where, instead of promoting Concoction"-that is, digestion- "it often causes a Cardilagium"-heartburn-"and fires the Blood: It should therefore be grosly contus'd only." Like pepper, mustard is "a necessary Ingredient to all cold and raw Salleting." Parsley, on the other hand, Evelyn finds "not so convenient in our crude Sallet," perhaps because in antiquity it was "never brought to the Table at all, as sacred to Oblivium and the Defunct." Robert Herrick, by the way, imitated the ancients by using parsley as a floral tribute in two of his funeral elegies, though he probably refrained from introducing this pagan herb into the funeral services he conducted as a functioning priest of the Church of England.

On the subject of garlic Evelyn is even firmer than on parsley, and for once we find him defying classical precedents: "We absolutely forbid it entrance to our Salleting, by reason of its intolerable Rankness." His only concession to garlic is to admit "a light touch on the dish, with a Clove thereof, much better supply'd by the gentler Roccombo," which is a kind of shallot. It is rather disappointing to find him sharing the common English prejudice against garlic, which, he admits, is "familiarly eaten with almost everything" by Spaniards and Italians. But in England " 'tis not for Ladies Palats, nor those who court them."

Some of the herbs on Evelyn's list, such as bugloss, borage, hyssop, thyme, and marigold, have more uses in general cooking and medicine than in salads. The medicinal properties of all his plants are never far from Evelyn's mind, and for this reason, Acetaria must be considered in the line of European herbals that stretches back through the Middle Ages to the Greeks. Evelyn's chief English predecessors were William Turner (I 55 I), Henry Lyte ( I 578), John Gerard ( I 597), Thomas Johnson (revised Gerard, I632), John Parkinson ( I 640), and Nicholas Culpepper ( I66 I). The works of these botanists provided for each plant a detailed physical description and often a woodcut, a discussion of its habitat and nomenclature, and a full treatment of its "virtues" or medicinal uses. Many of the entries, with their remedies for fear, forgetfulness, and rabies, strike a modern reader as quaint and myth-ridden. "Goose tree" in Gerard, for instance, is famous but not at all typical of that sensible herbalist. Found in the northern and watery parts of Scotland, this tree bears shells like those of molluscs, out of which hatch geese. I hasten to say that there are no credulities of 
this sort in Acetaria, though Evelyn has obviously inherited a lot of medical lore from his predecessors-lore that is frequently supplemented by Evelyn's personal experience. Thus endive is "naturally cold, profitable for hot stomachs"; daisies are "somewhat opening"; mallows are "friendly to the Ventricle"; fennel "expels Wind, sharpens the Sight, and recreates the Brain"; and so on. As in the herbals, almost every plant is good for something besides mere nourishment.

But unlike the herbalists, Evelyn has no interest at all in astrological botany, a pseudo-science which purported to state what heavenly body, what planet or constellation, has dominion over what plants, as when Gerard asserts that "Clary is under the moon," or "burdock is under Venus." Culpepper in particular based his whole system of cures on such fanciful dominions. "Wormwood," he says, "is an Herb of Mars," and he goes on to prove this claim syllogistically: a plant that delights in "Martial places" is martial; wormwood grows around forges and iron works, which are martial places; therefore wormwood belongs to the planet Mars. Evelyn warns against this kind of foolishness: "Let none consult Culpeper or the Figure-flingers"-i.e., astrologers-"to inform them when the governing planet is in Exaltation; but look upon the plants themselves, and judge of their Vertues by their own Complexions." In the latter part of this sentence there may be a suggestion of the doctrine of "signatures," which held that the very appearance of a plant proclaims its medicinal uses. Thus walnuts are indicated for sick brains, and spotted comfrey-the ancient "lungwort"-for spots on the lungs. If Evelyn has some confidence in signatures, and there is evidence here and there in Acetaria that he does have, he is no different from most other people in combining credulity with rationality.

And if in many respects Acetaria resembles the herbals, in other ways it's like a primitive cookbook compiled before the days of precise directions and measurements. Evelyn is interested in all kinds of vegetable dishes, and throughout the book he pays almost as much attention to cooked vegetables, which he calls "pot herbs," as to raw or crude salad ingredients. Cabbages, he tells us, are "crass and melancholy," and although Parkinson in his herbal had said that the Romans ate them to cure all diseases, Evelyn wonders "at the veneration we read the Ancients had for them." If you boil 
them too long, they are astringent; if not long enough, they are loosening. Only the Dutch eat them raw. Evelyn prefers asparagus, carrots, beets, and turnips; he even includes his own recipe for turnip bread. It's a little hard to tell from the book just how much actual kitchen experience Evelyn has had. He does confess that he once made macaroons from sunflower seeds, but "the Turpentine did so domineer over all, that it did not answer to expectation." And at the end of Acetaria he appends directions for making thirtyfive different vegetarian dishes, but these, he says, he had from "an Experience'd Houswife." Whoever she was, her cooking seems to fit the English stereotype: her recipe for "Colyflowers," for instance, begins, "Boil them till they fall in pieces."

Evelyn himself has few food inhibitions. As the macaroon experiment indicates, he is ready to try almost anything once, from elder-flower fritters and bag puddings flavored with marigolds and pennyroyal to the weeds that he or his servants picked and dug from the hedgerows and verges of his estate. For his salads he recommends all sorts of buds, blossoms, roots, and shoots plucked from wild and cultivated plants. He would be content at a vegetarian dinner foraged by the late Euell Gibbons or some other modern food scavenger, for at least fifteen of the salad ingredients he lists are identifiable as common weeds-though of course neither Evelyn nor the food-faddist of today would ever use the pejorative term weeds. On Evelyn's list we find not only such staples of the wild diet as young dandelions, docks, and nettles, but also such gourmet weeds as samphire (known to readers of King Lear from Edgar's description of the samphire gatherer on the Dover Cliffs) and sow thistles (Milton ate them only figuratively, as when he referred to his education at Cambridge University as an "asinine feast of sowthistles and brambles"). Although Evelyn is careful to give Latin names for each of his weeds, it's still not easy to identify all of them today because he wrote before the Linnaean binomial system was adopted. But it seems safe enough to suggest that he ate, among others, weeds that now bear the following common names in England: fat hen, good King Henry or goosefoot, sea purslane, common mallow, and sorrel. Probably the sorrel was cultivated in Evelyn's elaborate gardens at Sayes Court. If so, we can envy him for having a good supply of this delicious plant.

Obviously Evelyn enjoyed eating many different good things, 
but there were others, naturally enough, that he just didn't like. His heretical views on cabbage and garlic have already been mentioned, and now it must be confessed that he also didn't want raw spinach in his salads, or mushrooms - although the longest entry in his catalogue of salad ingredients is devoted to mushrooms. Evelyn knows a lot about edible fungi, "these rank and provocative Excrescenses," but he is suspicious of them on two grounds: they imply a voluptuousness of diet that offends him, and they are potentially dangerous. They should be, he says, "banished entry to our Sallet, were I to order the Composition," and he cites some "Accidents they have produc'd, not only to particular Persons, but whole Families." Throughout Acetaria there runs an undercurrent of warning against eating poisonous plants, against being "mistaken in the Names of divers Simples, not yet fully agreed upon among the Learned in Botany." It's odd, then, that among the recipes in the Appendix of Acetaria Evelyn mentions eating the "small green Fruit" of the potato plant, because these cherry-like growths are now widely regarded as poisonous. As for potato salad, Evelyn doesn't refer to it, though long before his time Gerard had said of potatoes that some people "dresse them (first being rosted) with oile, vinegar, and salt." Nor does Evelyn make salads out of that other great gift of the New World to the Old, the tomato. I can find no mention at all of tomatoes in Acetaria, though again Gerard, who calls them "love apples," says that they are eaten in Spain both stewed and raw with oil, vinegar, and pepper. Whether Gerard himself ate them he doesn't say, but he admits to growing them in his garden, where they "doe increase and prosper."

Aside from these omissions and expressions of individual taste, Evelyn -in most other respects a True-Born Englishman-is extraordinarily sound on the subject of salads, especially in comparison with some later compatriots. "My appetites are too high for the salads which . . . Eve dressed for the angel" in Paradise Lost, remarked Charles Lamb, speaking, one feels for most of his race. When, in Edroin Drood, John Jasper and Thomas Sapsea sit down to a supper of "cold roast beef and salad," we can be almost certain that Dickens is referring to a plate loaded with meat and garnished with a few dead vegetables. Since Evelyn's time this sort of decoration has become known as "salad" in the British Isles. Even nowadays, when a dish resembling a tossed salad is served (except 
in expensive or ethnic restaurants), it is likely to be soaked in a watery, semi-sweet dressing. Sanctions for this abomination can be found in surprising places. For instance, Sir Samuel Luke's The Tenth Muse (1954, I 962), which contains elaborate recipes for posh dishes of duck, game, lobster, and veal, includes sugar among the ingredients of what it calls "Vinaigrette Sauce" as well as "French Salad Dressing." And in his concluding chapter of "Dont's," Sir Samuel warns us not to forget adding "a pinch of sugar to green salads." Evelyn, in commendable contrast, says that "now Sugar is almost wholly banish'd" from the salads served at the "best Tables."

Evelyn's own directions for composing and dressing a salad would not raise an eyebrow on any respected food writer today. First, he says, the ingredients must be selected, a task much more demanding for Evelyn than for those of us who are dependent on supermarkets for our greens. Selection is a matter of art: "in the Composure of a Sallet, every plant should come in to bear its part, without being over-power'd by some Herb of a stronger taste, so as to endanger the native Sapor and vertue of the rest; but fall into their places, like the notes in Music, in which there should be nothing harsh or grating." Evelyn develops at some length this quasi-metaphysical analogy between salads and music. For the novice salad-maker, he provides an elaborate fold-out table, arranged according to the seasons and showing the proportions of various ingredients to use in a salad. In compiling the table, he acknowledges the assistance of George London, King William's head gardener and proprietor of an important commercial nursery.

After the "Herby Ingredients" have been chosen, Evelyn tells us they should be "exquisitely cull'd and cleans'd of all worm-eaten, slimy, canker'd, dry, spotted, or in any ways vitiated Leaves." Then, after washing and draining them in a "Cullender," the salad maker should "swing them altogether gently in a clean course Napkin; and so they will be in perfect condition to receive the Intinctus"-that is, the oil, which should be "smooth, light, and pleasant upon the Tongue; such as the genuine Omphacine and native Luca Olives afford," and the vinegar, which should be "perfectly clear, neither sowre, Vapid, or spent . . . the best Wine Vinegar." Evelyn admits only three other ingredients into his classic dressing: salt, pepper, mustard. With the great array of freshly picked salad greens he has available, he can afford to be a purist; his salad doesn't 
need blue cheese, bacon rinds or monosodium glutamate to give it flavor. It's a pleasure to think of him three hundred years ago, cutting a lemon with a silver knife (to avoid the "Metalic relish" of steel) or discussing with his guests a question that still vexes us, as it vexed the ancient Romans, whether the salad course should come before or after the "harder meats."

Although Evelyn never completed the great horticultural opus that he planned to write, in the Acetaria he gave posterity a delightful book which, even better than his famous Diary, reveals his attractive character: his wit, eloquence, curiosity, enthusiasm, learning, and

Veneration and Admiration of the infinitely wise and glorious Author of Nature, who has given to Plants such astonishing Properties; such fiery Heat in some to warm and cherish, such Coolness in others to temper and refresh, such pinguid Juice to nourish and feed the Body, such quickening Acids to compel the Appetite, and grateful Vehicles to court the Obedience of the Palate, such Vigour to renew and support our natural Strength, such ravishing Flavour and Perfumes to recreate and delight us: In short, such spirituous and active Force to animate and refresh every Faculty and Part, to all kinds of Human, and I almost said Heavenly capacity too. 